\title{
Salt Tolerant Paddy Varieties, Showing Resistance to Brown Spot during Nursery Stage
}

\author{
Vikash Chandra $^{1 *}$, Dheeraj K. Tiwari ${ }^{1}$, A.K. Singh ${ }^{2}$, Sunil Singh ${ }^{1}$, Ratna Sahay ${ }^{1}$, \\ Archana Singh ${ }^{1}$ and Ramesh Chandra Maurya ${ }^{1}$ \\ ICAR-Krishi Vigyan Kendra, Unnao-229881Uttar Pradesh (India) \\ *Corresponding author
}

\begin{abstract}
Keywords
AUDPC, Brown spot, Disease incidence, Disease index, Salt tolerant and Silicon

Article Info Accepted: 07 November 2018 Available Online: 10 December 2018 affected in India, having longer water stagnation capacity, though having deficiency of organic matter and other essential nutrient, where during monsoon season only paddy is grown. In the present study twelve varieties of paddy were evaluated in salt affected soil, during nursery conditions, and was observed that variety developed for salt tolerance (CSR30. CSR 36 and CSR 46) to BS disease in all the parameter like Disease incidence (DI), Disease Index and AUDPC value whereas, these parameter were highest for scented variety (Kala Namak) having GI in Uttar Pradesh (India) have disease incidence (69.75 and $66.25 \%$ ) fine grained variety Ganga Kavery with average DI of $60 \%$ and $60.75 \%$, were more susceptible to the disease in both year (2017 and 2018). During the observation it was depicted that both DI and AUDPC values varies according to the disease incidence. It was hypothesized that absorption of Silicon a beneficial nutrient (a major mineral element conferring resistance to the BS) and conferring Salt tolerance to the plant varieties salt tolerant varieties (CSR30, CSR36 and CSR 42) is more efficient and then the other available varieties. Further, it was also observed that in the salt affected main field, along with normal rainfall reduces disease incidence without any chemical fungicide application.
\end{abstract}

\section{A B S T R A C T}

Brown spot caused by (Bipolaris oryzae) is a persistent disease of Paddy (Oryza sativa L.) and associated with reduction in economic yield in the areas under dry and semi dry climate, with the nutrient poor field. Part of the paddy area under cultivation is salt

\section{Introduction}

Paddy (Oryza sativa L.) is a starch food crop ranks third in world after maize and wheat to supply feed for world population and enjoy first position in Asia (Aryal et al., 2016). In India paddy is cultivated in 43.86 million ha., with the annual production level 104.80 million tones and productivity of $2390 \mathrm{~kg} / \mathrm{ha}$ (Agriculture - Statistical Year Book India
2017). Paddy crop is suffered by a number of diseases and pests out of which disease brown spot caused by Bipolaris oryzae Ou (1972) and is considered to be chronic one affecting thousands hectares of paddy crop, thus causing not only in terms of incurring losses in grain yield $4-52 \%$ of the paddy crop (Barnwal et al., 2013), but historically causing famous Bengal famine in 1942 and killing millions of innocent people of the country (Chakrabarti $e t$ 
al., 2001; Padmanabhan, 1973). The disease is prevalent under dry and semi-dry conditions and has been noted to reduce yield by reducing germination percentage of infected seeds, photosynthetic Leaf area reduction, resulting in the reduction of yield. Infection results in weakening of the plants (Wang et al., 1978; Sundar, 2014). Apart from paddy field or soils, paddy straw and stubble, infected paddy seeds are likely sources of primary inoculums for paddy brown spot epidemics. The disease is reported to be more severe in nutrient deficient soil especially $\mathrm{K}$ as limiting factor aggravate the disease (Zadoks 1974) India is having 6.74 million ha area under soil salinity (Mandal et al., 2009) of which approximately of 2.46 million ha soil is suffering from water logging in country, where paddy cultivation, is practiced, this kind of soil is basically low in nutrient content especially in essential nutrient Phosphorus (P) (Singh et al., 2006; Agostinho et al., 2017) and Silicon ( $\mathrm{Si}$ ) which is beneficial element for plant growth especially for the members of family of Poacae and cucurbitacae (Epstein E. (2009). Epstein and Bloom, 2005; Ma and Yamaji, 2008) required for plant sustainability and confers disease resistance against $B$. Oryzae (Nanda et al., 1984; Yamauchi et al., 1987; Leandro et al., 2014; Datnoff et al., 1990; Datnoff et al., 1991) which is normally available to in the soil at $\mathrm{PH}$ range of 5.5-6.5 as mono silicic acid (McKeague and Cline (1963) which is the form absorbed by Plant. Paddy is cultivated in the form of Direct Seeded Rice in dry or semi dry areas, Transplanted rice in large area under irrigation and SRI method in few pockets. For the transplantation of paddy, seeds are grown in nursery $\left(1 / 10^{\text {th }}\right.$ area of field to be transplanted) when the seedlings become of 25-30 days old, seedlings are uprooted and transplanted in the field..

Raising of disease free nursery is the prime importance, as the soft seedling is prone to be attacked by large number of diseases and
Insect Pests, which if not controlled reaches to the main paddy field and affects crop growth followed by yield (Ibaraki T. 1988). Interaction among availability of plant nutrient in the soil, climatic condition, presence of pathogen inoculums, and plant variety plays the deciding role in development of disease. Although biological and chemical control is available for the management of brown leaf spot (Gupta V et. al 2018), host plant resistance is most economical and environment friendly and it is desirable to have plant variety in hand having endurance to multiple biotic and abiotic stresses. In the present study, nursery of twelve varieties of the paddy were raised at the Farm of ICARKrishi Vigyan Kendra Dhaura Unnao (Longitude 80.6604483 and Latitude 26.8154276) during kharif seasons of 2017 and 2018 using scientific methodology viz, and proper seed treatment, fertilization, irrigation etc. Crops were monitored routinely for incidence of diseases and pests and data were recorded with the objectives to find out suitable variety with minimum disease incidence.

\section{Materials and Methods}

\section{Paddy variety used for study}

In the present study following twelve varieties were evaluated, fine grained scented variety Kala Namak, Kala Namak Dwarf, Varieties showing tolerance against soil salinity (CSR30, CSR 36, CSR46), fine grained high yielding varieties (NDR3112, NDR2064, NDR359, Ganga Kaveri, NP 360, Shri Ram 502, and Chinnour).

\section{Soil condition and field preparation}

Soil of Krishi Vigyan Kendra, Farm located at Longitude 80.6604483 and Latitude 26.8154276 being salt affected with $\mathrm{PH}$ of nursery field 8.6, Electrical Conductivity 0.29 $\mathrm{ms} / \mathrm{cm}$., Organic matter content $0.31 \%$, clayey 
in nature, having hard calcareous layer below the 8-10 feet, soil is inherently low in essential element (NPK).Nursery was sown after wheat harvest, wheat straw (left over after crop harvest using combine harvester) was incorporated in the field by ploughing, followed by flooding, and application of 1 tone $/ 1000 \mathrm{~m}^{2}$ FYM. Field was flood irrigated and well ploughed with cultivator and Rotavatar and $40 \mathrm{~kg} / \mathrm{ha}$ DAPS and $10 \mathrm{Kg}$ MOP/1000 $\mathrm{m}^{2}$ was broadcasted.

\section{Seed treatment}

Seeds of all the varieties were soaked overnight in water and treated with Carbendazim 50\% WP (trade name Crostin by Shivalik Agro Chemicals) $2.5 \mathrm{gm} / \mathrm{kg}$ of seed, Plantimycin (Aries Agro) $6 \mathrm{gm} / 20 \mathrm{~kg}$ of seed, and Tricyclazole $75 \%$ W.P. (trade name Blaster manufactured by Sulphur Mills limited) $0.6 \mathrm{~g} / \mathrm{kg}$ seeds and kept in shade for germination.

\section{Sowing of seed and time}

Seeds of each variety were taken at the rate of $35 \mathrm{~kg} / \mathrm{ha}$ for nursery raising, and Pregerminated seeds were broadcasted in 1000 $\mathrm{M}^{2}$ area to transplant 1 ha paddy field. The nursery was shown every year $25^{\text {th }}$ of May.

\section{Crop management}

To control weeds in paddy nursery herbicide Pyrazosulfuron ethyl 10 WP (Sathi manufactured by UPL limited) was sprayed @ $215 \mathrm{gm} / \mathrm{ha}$. On the $3^{\text {rd }}$ day after the broadcasting of seeds, excess water was removed from the field. On $7^{\text {th }}$ day supplementary irrigation was given in the field by Flood irrigation. $60 \mathrm{Kg}$ Urea and $20 \mathrm{~kg}$ Zinc Sulfate were broadcast in the field for good seedling growth.

\section{Disease survey}

Nursery of paddy was monitored routinely from the date of sowing, for the incidence of disease and pest data were recorded from the year kharif 2017 and kharif 2018.

\section{Microscopy}

Affected plant sample was brought to the laboratory and microscopy of leaf sample was done as per method given by Quintana et al., (2017). The sample was observed at 100X using light microscope CosLab model HL-10.

\section{Disease incidence study}

The data for disease incidence were recorded at 7 days interval from the days of nursery sowing, to assess the incidence of disease on different varieties $1 \mathrm{X} 1 \mathrm{~m}^{2}$ area of each plot were selected randomly and number of infected plants were counted over total population. Disease scoring was done by using standard disease rating scale of IRRI, 2002, Aryal L., 2016 (Table 1).

\section{Disease index}

Disease severity was calculated as Disease index on 21 days after 28 days after nursery sowing of paddy nursery, disease index was calculated by the formula given by (Chaube HS and Pundhir, 2009).

$$
\begin{aligned}
& \mathrm{DI}=\left(0\left(\mathrm{X}_{0}\right)+1\left(\mathrm{X}_{1}\right)+2\left(\mathrm{X}_{2}\right)+3\left(\mathrm{X}_{3}\right)-\cdot-\cdot-\cdot-+\mathrm{n}(\mathrm{Xn}) /\right. \\
& \left.\mathrm{X}_{0}+\mathrm{X}_{1}+\mathrm{X}_{2}+\mathrm{X}_{3}-------+\mathrm{Xn}\right) \mathrm{X} 100
\end{aligned}
$$

Where $\mathrm{X}$ represents no of entries within a grade and 0 -and is the grade of disease as per disease rating scale. For the calculation of disease intensity $1 \mathrm{X} 1 \mathrm{M}^{2}$ areas was selected in each variety and 25 plants of each variety was selected randomly for the calculation of disease index 


\section{AUDPC curve study}

The progress of the disease within a nursery plant population was calculated by under disease progress curve (AUDPC), which gives the quantitative measure of disease development and the rate of disease development (Reynolds et al., 1997), also assist in to group varieties under distinct extent of hostility to the pathogen. It was calculated by summation of disease incidence observed over a fixed period of time, a formula given by Campbell et al., (1990) given as follows by

$$
\operatorname{AUDPC}=\sum_{\mathrm{i}=1}^{\mathrm{n}-1}\left(\mathrm{y}_{\mathrm{i}-1}+\mathrm{y}_{\mathrm{i}}\right) \mathrm{X} 0.5\left(\mathrm{ti}_{-1}-\mathrm{t}_{\mathrm{i}}\right)
$$

Where $\mathrm{n}$ is the number of observations

$\mathrm{Yi}=\mathrm{is}$ disease incidence at the $\mathrm{i}^{\text {th }}$ day

$\mathrm{Ti}=$ day on which the disease was scored

\section{Results and Discussion}

\section{Symptomatology}

Initial symptoms of the disease were observed in the in all the varieties as small spots on leaves which enlarges up to of $1-2.5 \mathrm{~cm}$ in length (Fig. 1A). Likewise, symptoms also appeared on leaf sheaths and coleoptiles. The affected nursery can often be seen from a distance as sun burn appearance due to the mortality of apical leaves of the seedlings, disease were more severe on Ganga Kaveri, Kala Namak, Kala Namak dwarf, Sri Ram 502 and NP 360 where more or less all the plant were infected, However few spots were seen on the variety CSR30, CSR 36, CSR46, NDR3112, NDR2064, NDR359 (Fig. 1B-M). However when all the varieties were transplanted in field at a spacing of $25 \times 25 \mathrm{~cm}$ using 2-3 seedling per hill disease incidence was reduced to negligible level without any chemical application.

\section{Microscopy}

In light microscope conidia of Bipolaris oryzae were seen as club shaped to cylindrical, generally curved, light brown to golden brown, with 6 - 12 horizontal cell walls, Data not shown, similar to described earlier in the literature (Subramanian, 1966, Lidia Quintana 2017).

\section{Incidence of the disease}

Incidence of the disease in all paddy variety was recorded at seven days, fourteen days, twenty one days and after twenty eight days for the two consecutive years highest average (Avrg) disease incidence was observed in paddy variety fine grained scented variety Kala Namak (KN) $(69.75 \%$ and $66.25 \%)$ followed by non scented fine grained variety Ganga Kaveri (G.Kaveri) (57.5\% and 60.75\%) while lowest incidence was observed for the varieties tolerant to the salinity (CSR 30 CSR36 and CSR 46) during the survey it was also observed that variety like Shriram 502 (SR 502), NDR 3112, NDR 2064, NDR 359, NP 360 and Chinnour have moderate level of disease resistance of whose data have been given below in table 3 and Figure 1, based upon disease rating scale, Host Response (HR) have been also given in the table.

\section{Disease Index (DI)}

Highest DI was for the variety Kala Namak (583 and 611 after 21 days (d) and $28 \mathrm{~d}$ in 2017 and 568 and 598 in same time interval in 2018) followed by Ganga Kaveri 534 and 593 after 21 days (d) and $28 \mathrm{~d}$ in 2017 and 520 and 589 in same time interval in 2018), followed by SR 502 and Kala Namak Dwarf and NP 360 NDR 3112 NDR 2064 NDR 359 and Chinnour data is given in table 4 and figure 2. While lowest Disease intensity value was the variety Developed to tolerate salt Stress viz CSR30, CSR36, CSR 46. When 
two years DI Value was plotted against Variety it certainly shows that variety Kala Namak Ganaga Kaveri, are more susceptible to the disease followed by Shriram 502, Kala Namak dwarf, NP 360 where as, Chinnour,
NDR 359, NDR2064, NDR 3112 shows moderate level of resistance to the disease to the disease and CSR30, CSR36, CSR 46 were resistant to the disease.

Table.1 The disease rating scale used for screening of rice varieties against brown spot caused

by Bipolaris oryzae

\begin{tabular}{|c|c|c|}
\hline Scale & \% infection (Plant Disease (Severity) & Host response \\
\hline $\mathbf{1}$ & No incidence & Immune \\
\hline $\mathbf{2}$ & Less than $1 \%$ & Highly Resistant \\
\hline $\mathbf{3}$ & $1-3 \%$ & Resistant \\
\hline $\mathbf{4}$ & $4-5 \%$ & Resistant \\
\hline $\mathbf{5}$ & $11-15 \%$ & Moderately Resistant \\
\hline $\mathbf{6}$ & $16-25 \%$ & Moderately Resistant \\
\hline $\mathbf{7}$ & $26-50 \%$ & Susceptible \\
\hline $\mathbf{8}$ & $51-75 \%$ & Susceptible \\
\hline $\mathbf{9}$ & $76-100 \%$ & Highly susceptible \\
\hline
\end{tabular}

Table.2 Incidence of disease in all the 12 variety for the year 2017-18 and 2018-19

\begin{tabular}{|c|}
\hline Variety \\
\hline Days \\
\hline KN $^{1}$ \\
\hline KND $^{2}$ \\
\hline CSR30 \\
\hline CSR 36 \\
\hline CSR46 \\
\hline NDR3112 \\
\hline NDR2064 \\
\hline NDR359 \\
\hline G.Kaveri \\
\hline NP 360 \\
\hline SR 502 \\
\hline Chinnour \\
\hline
\end{tabular}

2017-18

2018-19

\begin{tabular}{|c|c|c|c|c|c|c|c|c|c|c|}
\hline \multicolumn{5}{|c|}{ 2017-18 } & \multicolumn{5}{|c|}{ 2018-19 } & \multirow[t]{3}{*}{ HR } \\
\hline \multicolumn{5}{|c|}{ Plant Disease incidence (\%) } & \multicolumn{5}{|c|}{ Plant Disease incidence (\%) } & \\
\hline $7 \mathrm{~d}$ & $14 \mathrm{~d}$ & $21 \mathrm{~d}$ & $28 \mathrm{~d}$ & Avrg & $7 \mathrm{~d}$ & $14 \mathrm{~d}$ & $21 \mathrm{~d}$ & $28 \mathrm{~d}$ & Avrg & \\
\hline 41 & 68 & 81 & 89 & 69.75 & 37 & 64 & 82 & 87 & 66.25 & $\mathrm{~S}$ \\
\hline 18 & 32 & 49 & 61 & 40 & 26 & 39 & 50 & 58 & 43.25 & $\mathrm{~S}$ \\
\hline 3 & 5 & 11 & 25 & 11 & 4 & 7 & 18 & 27 & 14 & I \\
\hline 1 & 7 & 11 & 18 & 9.25 & 0 & 5 & 9 & 13 & 6.75 & I \\
\hline 0 & 5 & 13 & 15 & 8.25 & 2 & 4 & 6 & 18 & 7.5 & I \\
\hline 17 & 23 & 31 & 39 & 27.5 & 14 & 25 & 36 & 51 & 29 & $\mathrm{R}$ \\
\hline 9 & 19 & 27 & 29 & 21 & 9 & 17 & 29 & 42 & 24.25 & $\mathrm{R}$ \\
\hline 6 & 15 & 28 & 33 & 20.5 & 4 & 11 & 31 & 39 & 21.25 & $\mathrm{R}$ \\
\hline 24 & 49 & 78 & 89 & 60 & 22 & 51 & 79 & 91 & 60.75 & S \\
\hline 15 & 31 & 49 & 59 & 38.5 & 14 & 28 & 47 & 54 & 35.75 & S \\
\hline 25 & 37 & 52 & 68 & 45.5 & 21 & 27 & 53 & 71 & 43 & I \\
\hline 18 & 27 & 31 & 37 & 28.25 & 11 & 19 & 28 & 42 & 25 & $\mathrm{R}$ \\
\hline
\end{tabular}

Table.3 Calculated value of disease index for all the variety under evaluation

\begin{tabular}{|c|c|c|c|c|}
\hline Variety & \multicolumn{2}{|c|}{ Disease Index:2017-18 } & \multicolumn{2}{|c|}{ Disease Index:2018-19 } \\
\hline & $\mathbf{2 1 ~ d}$ & $\mathbf{2 8 ~ d}$ & $\mathbf{2 1} \mathbf{d}$ & $\mathbf{2 8 ~ d}$ \\
\hline Kala Namak & 583 & 611 & 568 & 598 \\
\hline Kala Namak Dwarf & 421 & 489 & 443 & 479 \\
\hline CSR30 & 169 & 198 & 164 & 186 \\
\hline CSR 36 & 151 & 183 & 157 & 181 \\
\hline CSR46 & 149 & 168 & 132 & 167 \\
\hline NDR3112 & 297 & 318 & 279 & 301 \\
\hline NDR2064 & 278 & 297 & 293 & 319 \\
\hline NDR359 & 237 & 262 & 243 & 369 \\
\hline Ganga Kaveri & 534 & 593 & 520 & 589 \\
\hline NP 360 & 393 & 428 & 381 & 405 \\
\hline Shri Ram 502 & 468 & 509 & 477 & 511 \\
\hline Chinnour & 256 & 302 & 245 & 298 \\
\hline
\end{tabular}


Figure.1A: Typical brown spot symptoms on paddy varieties, Symptoms on, B. Kala Namak Dwarf C. Kala Namak D. NDR352 E. NDR 3112 F. Ganga Kavery G. CSR 36 H.CSR 42 I. CSR 46 J. NDR2064 K. ShriRam 502, L Chinnour M. NP 360
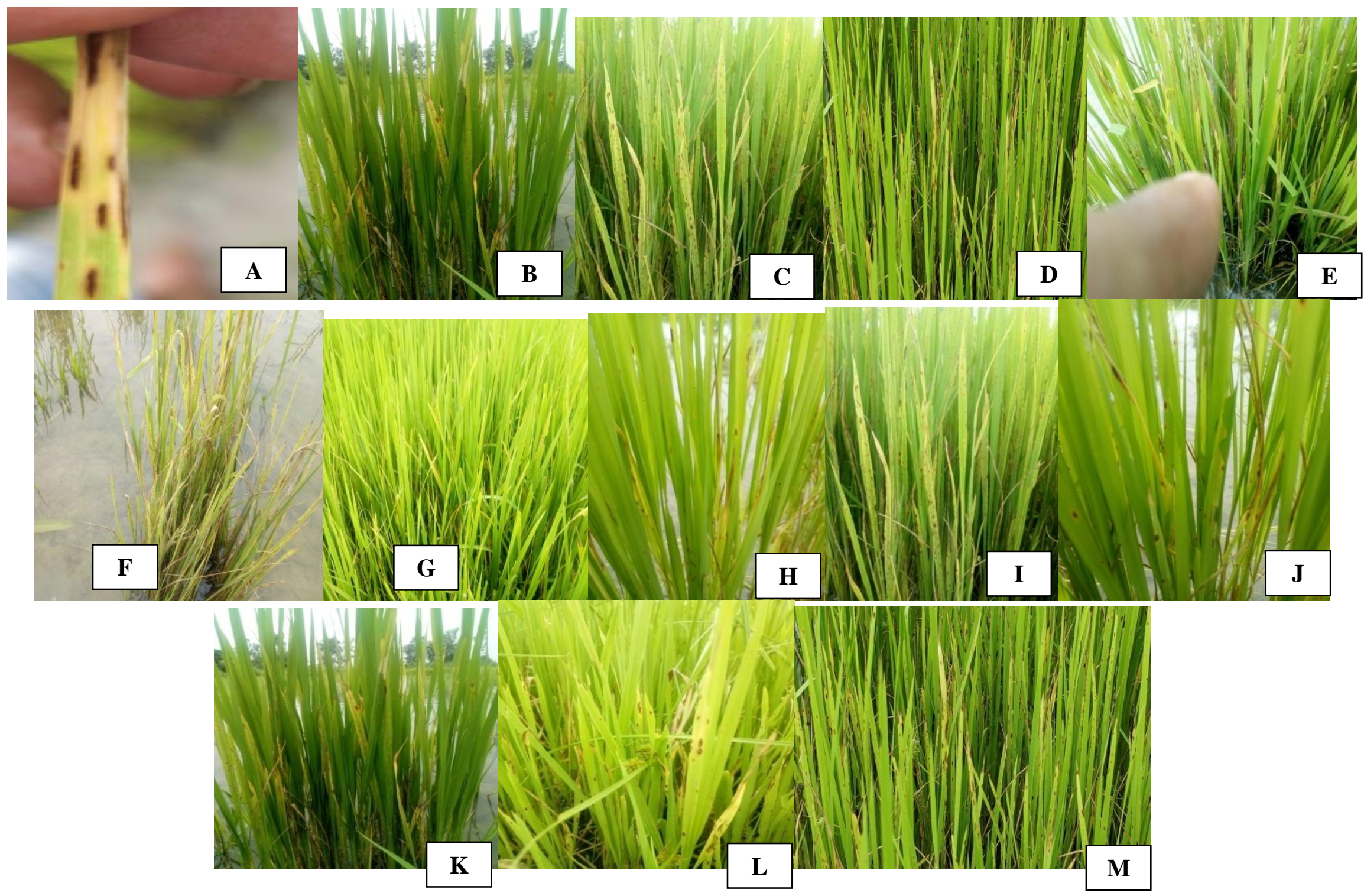
Fig.2 2A and 2B, Graphical representation of plant disease incidence of all the varieties in the 2017-18 and 2018-19

Graphical Representation of Progress of Plant Disease Incidence 2017-18

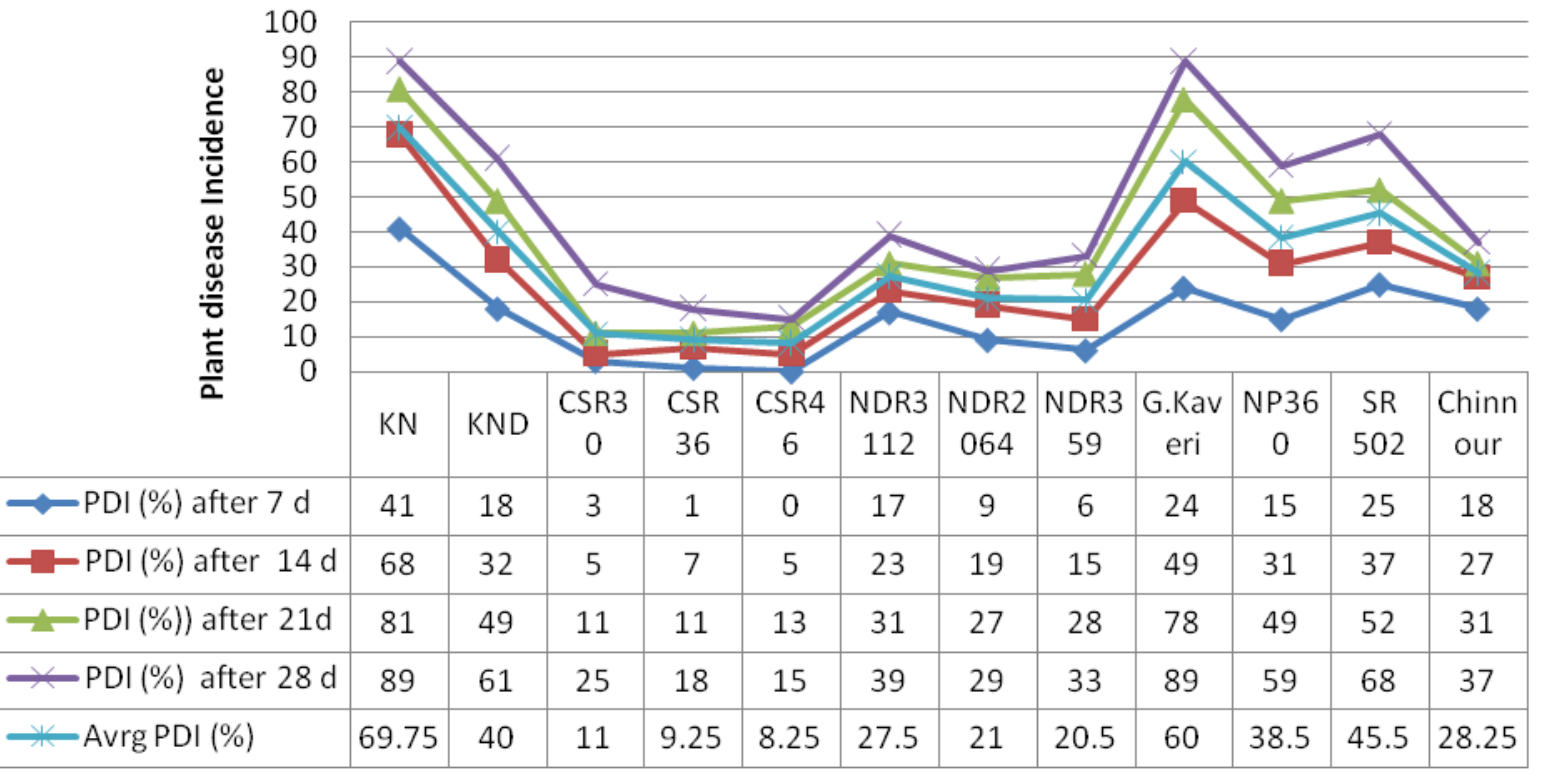

Fig.2 A

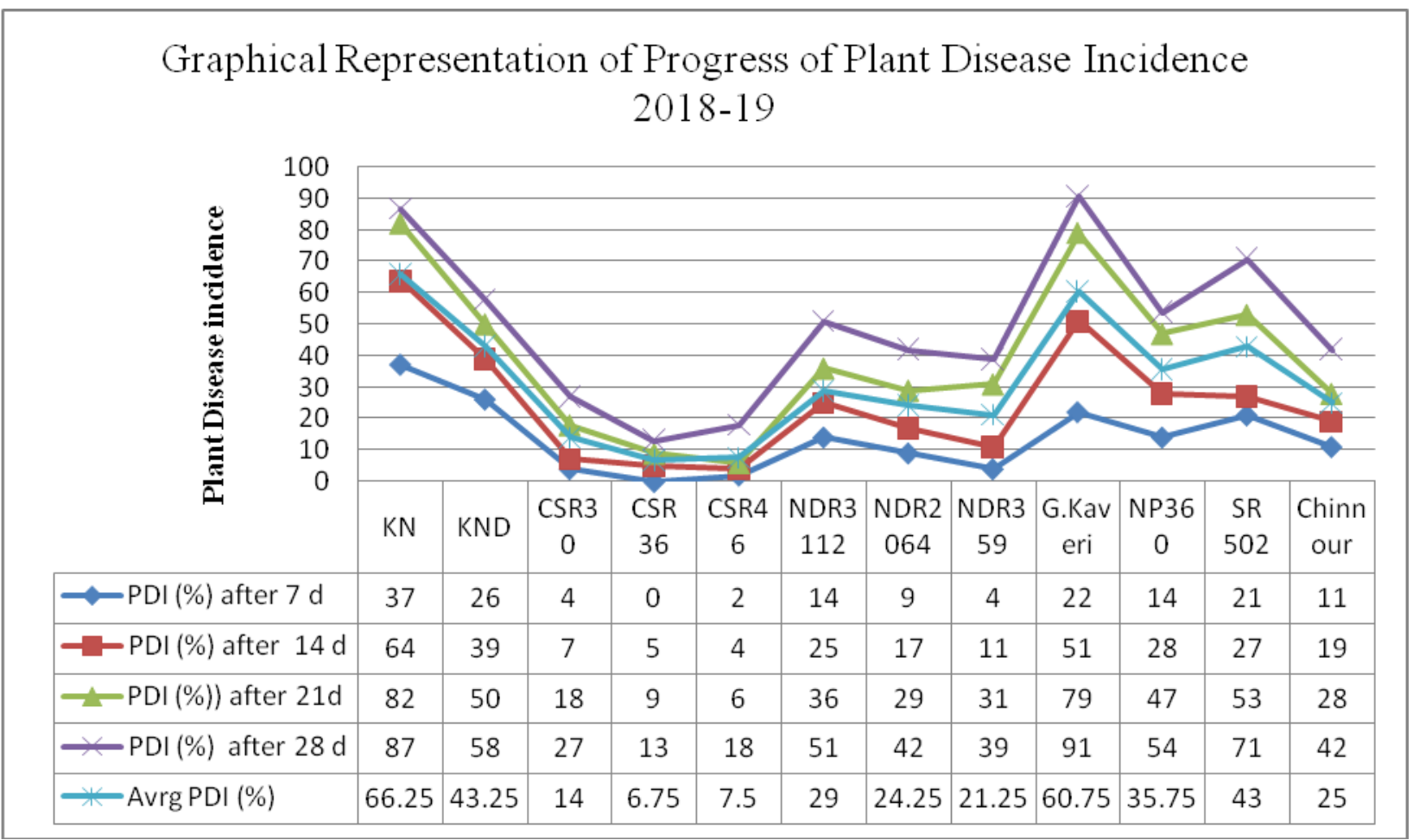

Fig.2B 
Figure.4 4A and 4B, Graphical representation of AUDPC obtained against disease in incidence of all the 12 varieties for the year 2017-8 and 2018-19

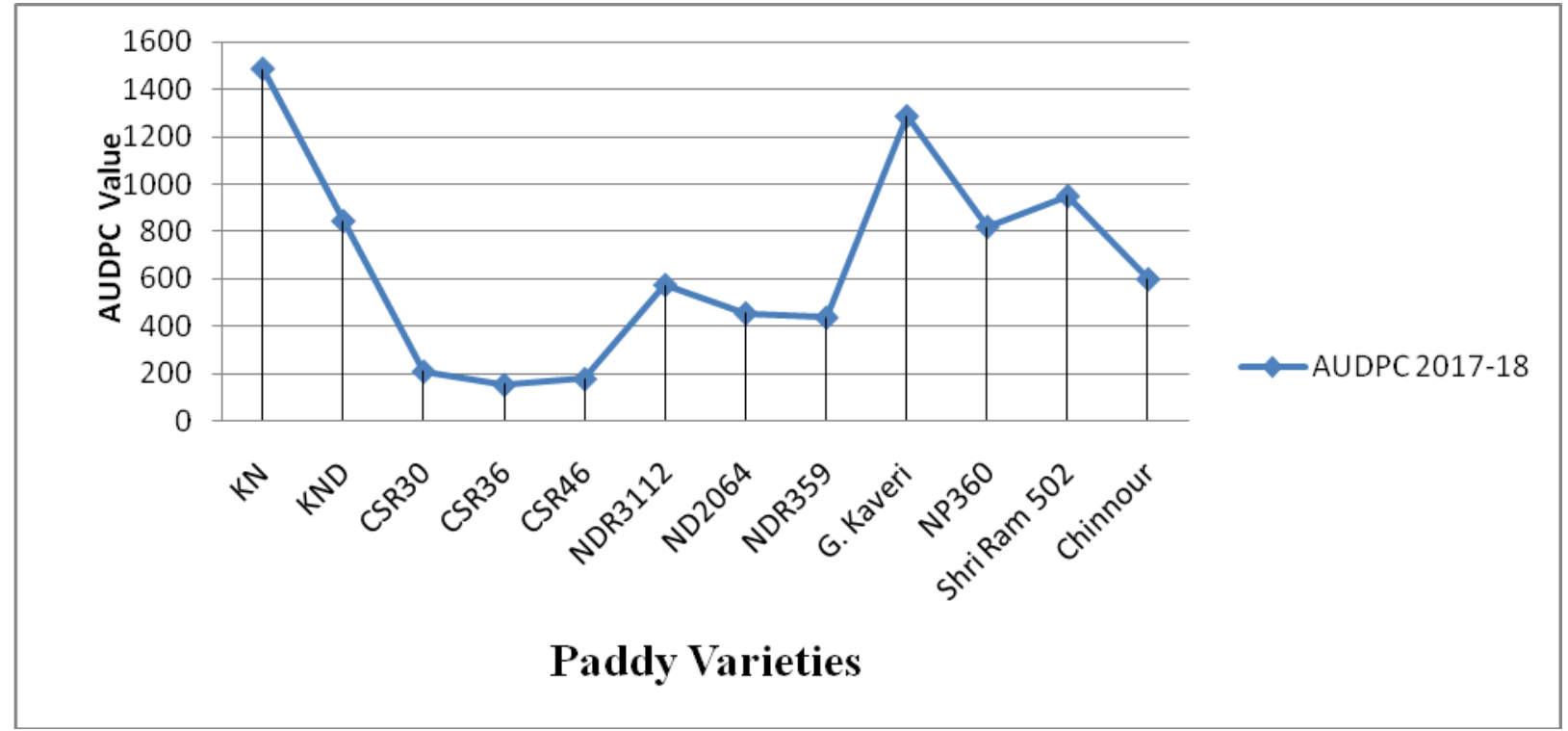

Figure 4 A

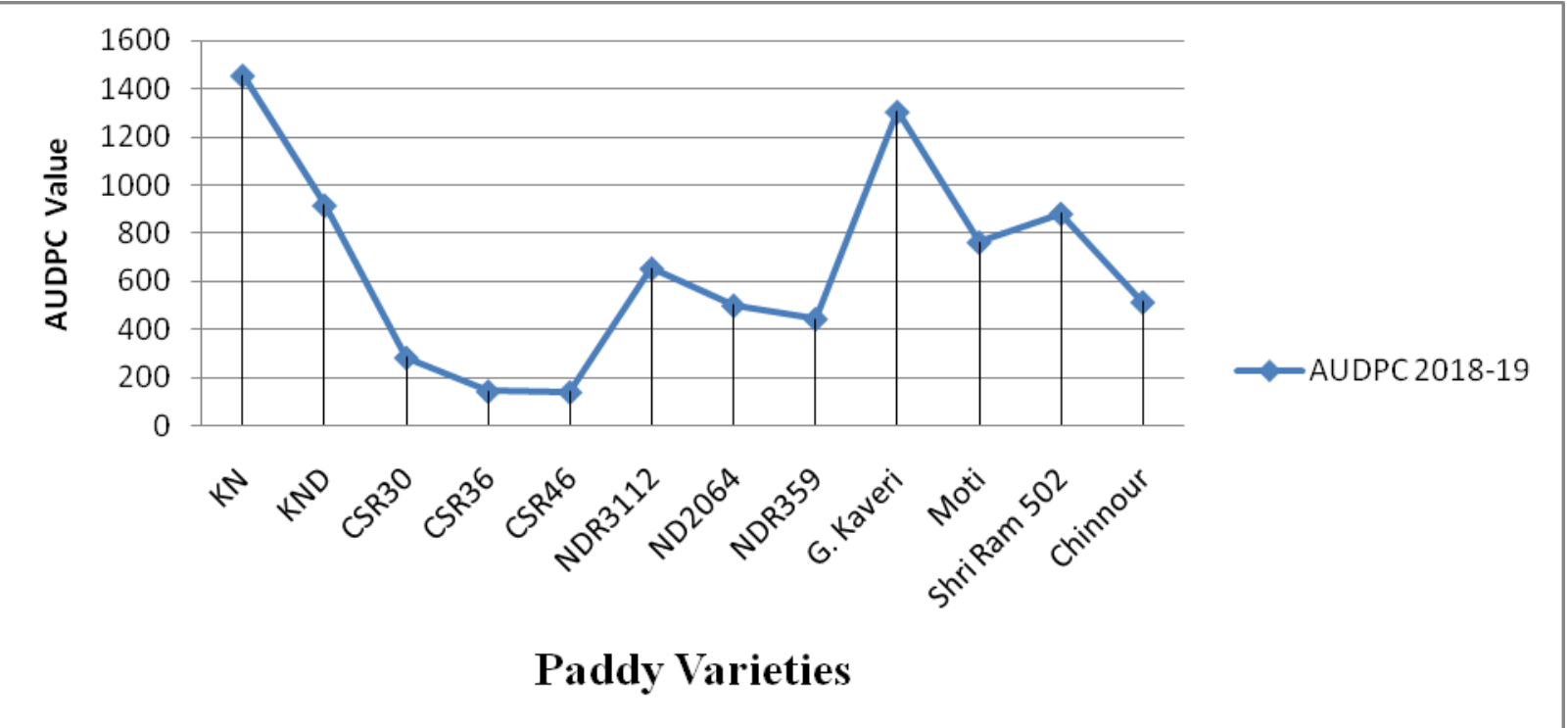

Figure 4 B 
Fig.3 Graphical reprenstaion of Disease index of all the varieties in the 2017-18 and 2018-19

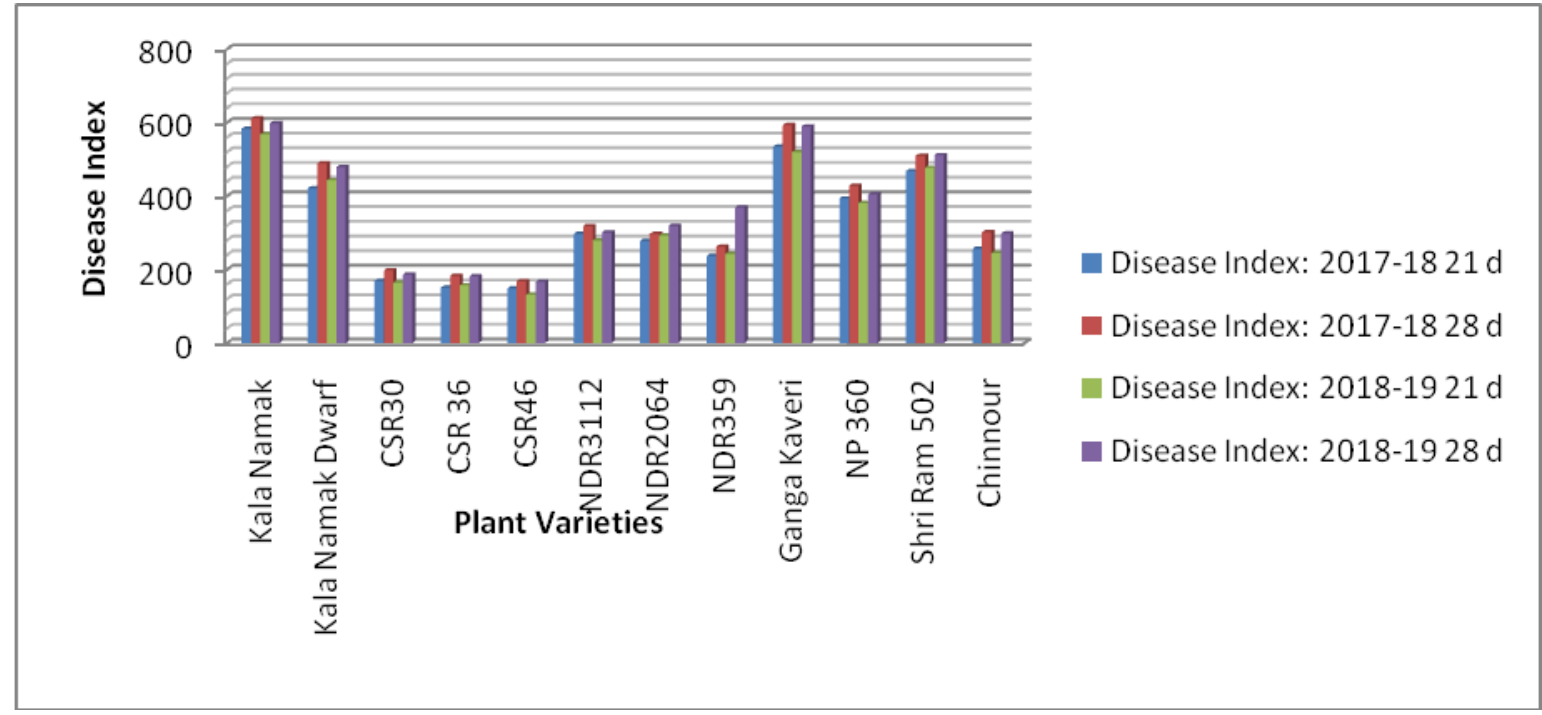

Table.4 Resistant category for twelve different varieties of rice based on mean AUDPC values on leaves at nursery condition in salt affected soil

\begin{tabular}{|l|l|l|}
\multicolumn{1}{|c|}{ Mean AUDPC Value } & \multicolumn{1}{|c|}{ Host Response } & \multicolumn{1}{c|}{ Code } \\
\hline $\mathbf{0 - 2 5 0}$ & Immune & I \\
\hline $\mathbf{2 5 0 - 5 0 0}$ & Resistance & R \\
\hline $\mathbf{5 0 0 - 7 5 0}$ & Moderately Resistance & MR \\
\hline $\mathbf{7 5 0 - 1 0 0 0}$ & Susceptible & S \\
\hline $\mathbf{1 0 0 0}$ and above & Highly Susceptible & HS \\
\hline
\end{tabular}

Table.5 Area under disease progress curve value of two years of all the variety under screening

\begin{tabular}{|l|c|c|c|c|c|c|c|c|c|c|c|c|}
\hline Var. $\rightarrow$ & $\begin{array}{c}\text { Kala } \\
\text { Namak }\end{array}$ & $\begin{array}{c}\text { Kala } \\
\text { Namak } \\
\text { dwarf }\end{array}$ & $\begin{array}{c}\text { CSR } \\
\mathbf{3 0}\end{array}$ & $\begin{array}{c}\text { CSR } \\
\mathbf{3 6}\end{array}$ & $\begin{array}{c}\text { CSR } \\
\mathbf{4 6}\end{array}$ & $\begin{array}{c}\text { NDR } \\
\mathbf{3 1 1 2}\end{array}$ & $\begin{array}{c}\text { NDR } \\
\mathbf{2 0 6 4}\end{array}$ & $\begin{array}{c}\text { NDR } \\
\mathbf{3 5 9}\end{array}$ & $\begin{array}{c}\text { Ganga } \\
\text { Kaveri }\end{array}$ & $\begin{array}{c}\text { NP } \\
\mathbf{3 6 0}\end{array}$ & $\begin{array}{c}\text { Shri } \\
\text { Ram } \\
\mathbf{5 0 2}\end{array}$ & Chinnour \\
\hline $\begin{array}{l}\text { AUDPC } \\
\mathbf{2 0 1 7}-18\end{array}$ & 1484 & 843.5 & 210 & 154 & 178.5 & 574 & 455 & 437.5 & 1284.5 & 819 & 948.5 & 598.5 \\
\hline $\begin{array}{l}\text { AUDPC } \\
\mathbf{2 0 1 8}-19\end{array}$ & 1456 & 917 & 283.5 & 143.5 & 140 & 654.5 & 500.5 & 444.5 & 1305.5 & 763 & 882 & 514.5 \\
\hline $\begin{array}{l}\text { Mean } \\
\text { AUDPC }\end{array}$ & 1470 & 880.25 & 246.75 & 148.75 & 159.25 & 614.25 & 477.75 & 441 & 1295 & 791 & 915.25 & 556.5 \\
\hline $\begin{array}{l}\text { Host } \\
\text { Response }\end{array}$ & HS & S & I & I & I & MR & R & R & HS & S & S & MR \\
\hline
\end{tabular}

\section{Area under disease progress curve}

Based upon plant disease incidence data recorded after 7 days interval and given in table 2), Area Under Disease Progress Curve was calculated for all the 12 varieties by the formula as given above with value of $n$ equal to 4 and Highest AUDPC value was obtained for the Kala Namak (1484 and 1456 for 201718 and 2018-19) and Ganga Kaveri (1284.5 
and 1305.5 for 2017-18 and 2018-19) followed by Shri Ram 502, Kala Namak dwarf and NP 360 value given in the table 4 while lowest value of AUDPC was for variety CSR 36, (154 and 143.5) CSR 46 (178.5 and 140) and CSR 30 (210 and 230) for both the year 2017-18 and 2018-19 where as moderate AUDPC value was obtained series and NDR359 NDR 2064, NDR3112 and Chinnour. When AUDPC Value was plotted against the plant variety two peaks were obtained in both the year one was for Kala Namak and second was for Ganga Kaveri followed by Shriram 502, Kala Namak Dwarf and NP 360, while least was gain for CSR 36 CSR 46, CSR 30. Based upon AUDPC value a scale was developed to recognise host Response which is given in table 4, and host response is given in table 5 (Fig. 4).

From the figures 3 it is clear that disease progresses with increase in time, and this increase was more in the nursery of Kala Namak, Ganga Kaveri followed by Shri Ram 502, Kala Namak dwarf, NP 360, and NDR Series and Chinnour, disease progresses was least in case of CSR series of varieties (especially bred for salt tolerance).

There was wide variation in the timing of symptoms development in all the twelve paddy varieties. The earliest symptoms reported in the paddy variety Kala Namak (Local scented rice) akin to Basmati Rice followed by Ganga Kaveri, Shri Ram 502, Kala Namak Dwarf, NP 360 and. Incidence of the disease increases with the time in all the 12 varieties and it was observed that Highest disease incidence was for variety Kala Namak and Ganga Kaveri followed by Shri Ram 502, Kala Namak Dwarf, NP 360, lowest disease incidence was observed for the varieties developed for salt tolerance viz CSR 36, CSR 42, CSR 46 and severity of the disease and Area Under Disease Progress curve also varies with variety as shown in the disease index table 3 and 5. Huge research data is available on the effect of plant nutrition and effect of climatic condition in incidence of brown spot in paddy. With the data recorded during study the sowing of paddy nursery at end of May, where there is no rainfall, artificial irrigation is provided to supplement the water requirement. As considered Bipolaris oryzae is mostly seed, soil \& weed born pathogen (Ellis et al., 1971; Nyvall et al., 1999; Biswas et al., 2008) and require optimum temperature $25^{\circ} \mathrm{C}$ and relative humidity of $>89 \%$ and free water on leaves (Dasgupta et al., 1977; Percich, 1997; Minnatullah et al., 2002) these conditions are easily met to the early sown nurseries as of Pre-Monsoon activities which favour earlier disease development. Incidence of the disease vary significantly in all the varieties, variety developed for salt affected soil have lowest disease incidence, lowest disease index and AUDPC value, reason may be due to effect of plant nutrition, $\mathrm{Si}$ is seems to be low in salt affected soil (Liang et al., 1994; Tavakkoli et al., 2011; Datnoff, 1991; Coskun et al., 2016). to young seedlings, the salt tolerance is high for these varieties (CSR30, CSR-36, CSR46), which may be strengthened by Si by binding $\mathrm{Na}^{+}$to the root zone of paddy (Gong et al., 2006; Rios et al., 2017; Fageria et al., 2014), and wheat Ahmad et al., (1992) by reducing rate of transpiration (Agarie et al., 1998; Nanayakkara et al., 2008) thus reducing free water availability in plant surface required for pathogen germination, silicification to the leaves surface Flowers T. J (1994), also reduces rate of penetration by the pathogen, these varieties, may have adoption for salt tolerance by more efficient uptake of Silicon. Si is an semi essential plant nutrient conferring resistance to plant against fungal pathogen (Leandro et al., 2014) higher uptake of silicon is also reported to stop pathogen for utilisising host ethylene pathways (Fadzilla et al., 1997 and Jonas Van Bockhaven et al., 2015). This is also in favour 
of salt tolerant variety being resistance to Bipolaris oryzae. It is also observed previously paddy variety differ in utilization of silicon from the soil. (Ma et al., 2007; Sahebi et al., 2017), and varietal difference were also observed in the incidence of brown spot disease Magar (2015), varieties like Kala Namak, Ganga Kaveri, are tall in height and very much prone to the lodging, which may be due to deficiency of Silicon in the soil and deferential ability of genotype of paddy to uptake silicon. Varieties like Kala Namak Dwarf, NP 360, Shri Ram 502, NDR3112.NDR 359 and NDR 2064, have shown partial resistance to the disease may be up taking $\mathrm{Si}$ in some amount which is in support of work done by (Idris et al., 1975; Majumadar et al., 1985). Secondly closer spacing in the nursery may have provided conducive microclimate for the disease spread among population Mondal et al., (2013). During observation of symptoms on crop management, one interesting observation was made when the infected nursery was transplanted in the main paddy field followed by regular rainfall due to monsoon, incidence of the disease was reduced significantly without any application of the chemical application this might be due to proper spacing and monsoon downpour may have washed the infected propagule from the plant surface, and due to water stagnation in the field (having salt affected soil) having high water retention capacity in soil, conidia were not able to germinate and subsequent crop life cycle was free from the disease (Brown spot). In the Survey of twelve paddy varieties for the two consecutive years (2017-18 and 201819), have revealed that Variety Kala Namak and Ganga Kaveri were highly susceptible to the disease followed by Shri Ram 502 Kala Namak dwarf, were fall in susceptible category where as by NDR 3112, NDR 359, NDR 2064 and Chinnour have shown some level of resistance to the pathogen at nursery conditions, whereas Variety bred for the salt tolerance viz CSR30, CSR32, CSR46 were more or less immune to the disease, having drawback of being bold seeded, and thus less acceptance among Farmers. Thus there is need to understand the mechanism of susceptibility and resistance in all the variety and also to identify the genetics mechanism of Indian paddy variety, so that resistance mechanism of the coarse seeded salt tolerant variety can be transferred to the fine grain scented Rice varieties viz., Kala Namak a tall scented paddy variety, having higher preference among farmers, high market value, and other high yielding varieties like Sri Ram 502, Kala Namak Dwarf, NP 360 and other fine grained high yielding varieties.

\section{References}

Agarie S H U, Agata W, Kubota F, Kaufman $P$ B (1998) Effects of silicon on transpiration and leaf conductance in rice plants (Oryza sativa L.). Plant Production Science 1: 89-95.

Agriculture - Statistical Year Book India 2017, http://mospi.nic.in/statisticalyear-book-india/2017/177.

Ahmad R, Zaheer S H, Ismail S (1992) Role of silicon in salt tolerance of wheat (Triticum aestivum L.). Plant Sci 85: 43-50.

Baranwal MK et al., (2013) A review on crop losses, epidemiology and disease management of rice brown spot to identify research priorities and knowledge gaps. European Journal of Plant Pathology 136: 443-457.

Biswas S K, Ratan V, Srivastava S S L, and Singh R (2008) Influence of seed treatment with biocides and foliar spray with fungicides for management of brown leaf spot and sheath blight of paddy. Indian Phytopathology 61: 5559.

Tavakkoli E, Lyons G, English P, and Chris N (2011) Silicon nutrition of rice is 
affected by soil $\mathrm{pH}$, weathering and silicon fertilization. Journal of Plant Nutrtion and Soil Science. 174: 437446.

Epstein, E (2009) Silicon: its manifold roles in plants. Annals of applied Biology 155: $155-160$.

Epstein, E, and Bloom A J (2005) Mineral Nutrition of Plants: Principles and Perspectives, 2nd Edn. Sunderland: Sinauer Associates Inc.

Fadzilla N M, Finch R P, Burdon R H (1997) Salinity, oxidative stress and antioxidant responses in shoot cultures of rice. Journal of Experimental Botany 48: 325-331

Fageria N K, Gheyi H R and Moreira A (2011) Nutrient bioavailability in salt affected soils. Journal of Plant Nutrition 34: (7) 945-962.

Agostinho F B, Tubana B S, Martins M S and Datnof L E (2017) Effect of Different Silicon Sources on Yield and Silicon Uptake of Rice Grown under Varying Phosphorus Rates Plants 6: 35.

Flowers T J, Hajibagheri M A, Yeo A R (1991) Ion accumulation in the cell walls of rice plants growing under saline conditions - Evidence for the Oertli hypothesis. Plant Cell Environment 14: 319-325.

Gong H J, Randall D P, Flowers T J (2006) Silicon deposition in the root reduces sodium uptake in rice (Oryza sativa L.) seedlings by reducing bypass flow. Plant Cell Environment 29: 1970-1979.

Chaube H S and Pundhir (2009) Crop diseases and their management PHI learning private limited p.173.

IRRI (2002) Standard Evaluation System for Rice (SES). International Rice Research Institute. Manila, Philippines. P. 13.

Ma J F, Yamaji N, Tamai K and Mitani N (2007) Genotypic Difference in Silicon Uptake and Expression of Silicon Transporter Genes in Rice. Plant
Physiol 145 (3): 919-924.

Rios J J, Martínez-Ballesta M C, Ruiz, Begoña Blasco $\mathrm{J} \mathrm{M}$ and Carvajal $\mathrm{M}$ (2017) Silicon-mediated Improvement in Plant Salinity Tolerance: The Role of Aquaporins. Front Plant Sci 8: 948.

Aryal L, Bhattarai G, Subedi A, Subedi M, Subedi B and Sah G K (2016) Response of Rice Varieties to Brown Spot Disease of Rice at Paklihawa, Rupandehi. Global Journal of Biology, Agriculture and Health Sciences 5(2): 50-54.

Leandro J, Dallagno F A, Rodrigues M V, Mielli B and Ma J F (2014) Rice grain resistance to brown spot and yield are increased by silicon. Tropical Plant Pathology 39(1): 056-063.

Quintana L, Gutiérez S, Arriola M, Morinigo K and Ortiz A (2017) Rice brown spot Bipolaris oryzae (Breda de Haan) Shoemaker in Paraguay. Tropical Plant Research 4(3): 419-420.

Ibrahim M A, Merwad A M,. Elnaka E A, Burras C L and Follett L (2016) Application of silicon ameliorated salinity stress and improved wheat yield. J Soil Sci Environ Manage 7(7): 81-91.

Sahebi M, Hanafi M M, Rafii M, Azizi Y P, Rambod A, Kalhori N and Atabakim N (2017) Screening and Expression of a Silicon Transporter Gene (Lsi1) in Wild-Type Indica Rice Cultivars Bio Med Research International, pp 13. https://doi.org/10.1155/2017/9064129

Idris Md, Hossain M M, and Choudhury F A (1975) The effect of silicon on lodging of rice in presence of added nitrogen Plant and Soil.43:3691-695.

Mondal M M A and Puteh A B (2013) Optimizing plant spacing for modern rice varieties. Int. J. Agric. Biol 15: 175-178

Nanayakkara U N, Uddin W, and Datnoff, L E (2008) Effects of soil type, source of silicon, and rate of silicon source on 
development of gray leaf spot of perennial ryegrass turf. Plant Dis 92:870-877.

Padmanabhan, S. Y (1973) The great Bengal Famine. Annual Review of Phytopathology 11: 11-26.

Percich J A, Nyvall R F, Malvick D K, and Kohls C L (1997) Interaction of temperature and moisture on infection of wild rice by Bipolaris oryzae in the growth chamber. Plant Dis. 81:11931195.

Magar P B (2015) Screening of rice varieties against brown leaf spot disease at jyotinagar, chitwan, Nepal. Int J Appl Sci Biotechnol 3(1): 56-60.

Nyvall R F and Percich J A (1999) Development of Fungal Brown Spot and Spot Blotch on Cultivated Wild Rice in Minnesota. Plant Disease 83: 936-938.

Reynolds L and Neher D A (1997) Statistical comparison of epidemics. In: L. J. Francl and D. A.Neher (Ed), Exercises in Plant Disease Epidemiology. APS Press, St. Paul, USA. pp. 34-37.

Sunder S, Singh R and Agarwal R (2014) Brown spot of rice: an overview. Indian Phytopathology 67(3): 201-215.

Agarie S, Uchida H, Agata W, Kubota F and Kaufman P B (1998) Effects of Silicon on Transpiration and Leaf Conductance in Rice Plants (Oryza sativa L.). Plant Production Science 1:2, 89-95.

Gupta V, Shamas N, Razdan V K, Mahajan S, Fatima K, Sharma S and Rai PK (2018) Management of Brown Spot of Rice (Oryza sativa L.) Caused by Bipolaris oryzae by Bio-ControlAgents. Int J Curr Microbiol App Sci 7(04): 3472-3477.

Liang Y C, Ma T S, Li F J and Feng Y J (1994) Silicon availability and response of rice and wheat to silicon in calcareous soils. Communications in Soil Science and Plant Analysis 25:1314.
Mandal A K, Sharma R C and Singh G (2009) Assessment of salt affected soils in India using GIS, Geocarto International 24(6): 437-456

Coskun D, Britto D T, Huynh W Q and Kronzuck H J (2016) The Role of Silicon in Higher Plants under Salinity and Drought Stress. Frontiers in Plant Science 7:1-7.

Datnoff L E, Raid R N, Snyder G H and Jones D B (1990) Evaluation of calcium silicate slag and nitrogen on brown spot, neck rot, and sheath blight development on rice. Biological and cultural tests for control of plant disease 5:65.

Datnoff L E, Raid R N, Snyder G H and Jones D B (1991). Effect of calcium silicate slag on blast and brown spot intensities, and yields of rice. Plant Dis 74:729-732.

Nanda H P and Gangopadhyay S (1984) Role of silicated cells in rice leaf on brown spot disease incidence by Bipolaris oryzae. Int J Trop Plant Dis 2:89-98.

Ou S H (1972) Rice Diseases. CAB International Mycological Institute, KEW, Surrey, England, p.368.

Bockhaven J V et. al, (2015) Silicon induces resistance to the brown spot fungus Cochliobolus miyabeanus by preventing the pathogen from hijacking the rice ethylene pathway. New Phytologist 206: 761-773.

Chakrabarti N K (2001) Epidemiology and disease management of brown spot of rice in India. In: Major Fungal Disease of Rice: Recent Advances. Kluwer Academic Publishers. pp. 293-306.

Ellis M B and Holliday P (1971) Cochliobolus miyabeanus. Descriptions of fungi and bacteria. UK: CAB International. 302 pp.

Singh R K, Singh C V and Shukla V D (2005) Phosphorus nutrition reduces brown spot incidence in rainfed upland rice. International Rice Research Notes 30(2), 31-32. 
Dasgupta M K and Chattopadhyay S B (1977). Effect of environmental factors on the development of brown spot of rice caused by Helminthosporium oryzae. Journal of the Society of Experimental Agriculturists 2: 24-27.

Minnatullah M D and Sattar A (2002). Brown spot development in Boro rice as influenced by weather condition. Journal of Applied Biology 12: 71-73.

McKeague J A and Cline M. G. (1963) Silica in soil solutions. II. The adsorption of monosilicic acid by soil and by other substances. Can. J. Soil Sci. 43: 83-96.

Campbell C L and Madden L V (1990) Introduction to Plant Disease Epidemiology. John Wiley \& Sons, New York. $532 \mathrm{p}$

Yamaji N, Mitatni N and JianFeng, M. (2008) A transporter regulating silicon distribution in rice shoots. The Plant
Cell 1381-1389.

Ibaraki T (1988) Diseases of Rice Seedlings Growing in the Nursery Box. JARQ 21(4):250-256.

Zadoks J C (1974) The role of epidemiology in modern Phytopathology. Phytopathology 64, 918-929.

Subramanian CV and Jain BL (1966). A revision of some graminicolous Helminthosporia. Current Science 14, 352-355.

Wang T S L, Hsu L S and Lin C H (1978) Study of relationship between soil fertility and brown leaf spot in rice. Soils Fertilizers Taiwan 1-25.

Majumder ND, Rakahit SC, Borthankur DN (1985) Genetics of silica uptake in selected genotypes of rice. Plant Soil 88: 449-453.

\section{How to cite this article:}

Vikash Chandra, Dheeraj K. Tiwari, A.K. Singh, Sunil Singh, Ratna Sahay, Archana Singh and Ramesh Chandra Maurya. 2018. Salt Tolerant Paddy Varieties, Showing Resistance to Brown Spot during Nursery Stage. Int.J.Curr.Microbiol.App.Sci. 7(12): 676-689.

doi: https://doi.org/10.20546/ijcmas.2018.712.084 